\title{
BRITISH MEDICAL JOURNAL
}

LONDON SATURDAY FEBRUARY 281959

\section{CLINICAL SIGNIFICANCE OF THE RHEUMATOID SERUM FACTOR \\ BY}

\author{
J. H. KELLGREN, M.Sc., F.R.C.P., F.R.C.S. AND J. BALL, M.D., B.Sc. \\ With the Assistance of FRIDA BIER, Dr. rer. pol. \\ From the Rheumatism Research Centre, University of Manchester and Manchester Royal Infirmary
}

Many human sera can be shown to contain a factor or factors which enhance certain antigen-antibody reactions; but this activity is present in relatively high titre in the serum of patients with rheumatoid arthritis. Since the report of Rose et al. (1948) sheep erythrocytes suspended in non-agglutinating doses of anti-sheeperythrocyte serum have been used extensively to titrate this rheumatoid serum factor, but other sensitized particles such as bacteria (Wager, 1950), polystyrene latex (Plotz and Singer, 1956), and bentonite (Bozicevich et al., 1958) may be employed. The results obtained with these various agglutinating systems indicate that they can provide a more or less reliable and specific aid to the diagnosis of rheumatoid disease (Ziff, 1957; McEwen et al., 1958).

Neither the mechanism of agglutination nor the nature of the rheumatoid agglutinating factor is fully understood. It is thought that the rheumatoid factor combines with a $\gamma$-globulin component (of human or animal origin) attached to the particle ; and a diagnostic test based on the precipitation which occurs between rheumatoid serum and $\gamma$-globulin (Cohn fraction II) from human plasma pools has been proposed (Epstein et al., 1956). The agglutinating activity of rheumatoid serum is located mainly in the $\gamma$-globulin fraction; it may be concentrated by various chemical fractionation procedures (Ziff, 1957), by elution from agglutinated erythrocytes (Greenbury, 1956), and by ultracentrifugation (Franklin et al., 1957), and by this last method the agglutinating activity has been shown to be associated with a $\gamma$-globulin of unusually high molecular weight.

In the routine titration of the rheumatoid agglutinating factor, some workers have preferred to use serum fractions rather than whole serum; and it would appear from published results that these offer some advantages as regards sensitivity and specificity (Svartz and Schlossmann, 1954 ; Hess, 1956 ; Ziff et al., 1956). In our hands such serum fractions have not proved more active serologically than the whole serum from which they were derived. Partly because of this and partly because we wished to collect sufficient data for meaningful analysis, we have, since 1948, continued to use the same method in both hospital practice and population surveys. The results of clinical trials up to 1950 (Ball, 1952) were based on titres recorded after incubation for one hour; but further experience has shown that the titres recorded after 18 hours' incubation give results which are more closely related to the clinical findings, so that the results of the 18-hours test have been used throughout the present analysis.

\section{Method}

The method uses sensitized sheep erythrocytes, the sensitivity of which is controlled by a series of human sera of known agglutinating activity. Different batches of haemolysin at a constant agglutinating or haemolytic dose often yield identical titres with a given human serum; sometimes small but definite differences occur, and rarely the differences may be very large. We have therefore found it necessary to arrive at the appropriate dilution of sensitizing antiserum by trial and error, using standard human sera as controls (Ball, 1950).

Whole human serum is inactivated and absorbed with normal sheep cells before titration. The titre is read after incubation for one hour at $37^{\circ} \mathrm{C}$. and again after refrigeration overnight at $4^{\circ}$ C. (approximately 18 hours).

The titre of a patient's serum tends to remain remarkably constant over a period of weeks or even months and bears no close relationship to the E.S.R. or clinical assessments of disease activity in the untreated or treated case (Ball, 1952; Ziff, 1957). In most cases the results of the sheep cell agglutination test (S.C.A.T.) remain rather constant over longer periods of time, and two illustrative cases are shown in Fig. 1.

Case 1 was a man aged 39 with severe nodular rheumatoid arthritis of six months' duration on admission to hospital. His agglutinating titre, tested on 32 occasions over a period of 18 months, remained consistently high. Case 2 was a man aged 30 with atypical spondylitis of five years' duration ; he developed severe involvement of all his peripheral limb joints and bilateral uveitis, and finally died from atlantoaxial dislocation, but his agglutinating titre, tested on 20 occasions over 18 months, remained persistently low. Occasionally, however, agglutinating titres do fluctuate substantially, as shown in Cases 3 and 4, both of which had definite rheumatoid arthritis of six months' duration when first tested. In Case 3, a man aged 45, the S.C.A.T. was strongly positive on admission but became negative for a period during the fourth year of his disease, when he was readmitted to hospital because of a severe allergic dermatitis ; whereas in Case 4, a woman aged 42, borderline S.C.A.T. titres initially rose to high levels during the third year of her disease, when she was readmitted for an exacerbation of her arthritis, and then became negative for a time during the fifth year. Both these cases developed articular erosions but neither had nodules.

From such examples it is clear that occasional negative tests occur in definite cases of rheumatoid arthritis at 
some stage of their disease, but too few of our patients have been tested routinely at regular periods of time irrespective of the state of their disease for us to be able to make any statement about the behaviour of the test during periods of remission and exacerbation of the disease.

Such studies have been carried out by de Forest $e t$ al. (1958) on a small number of patients and they found
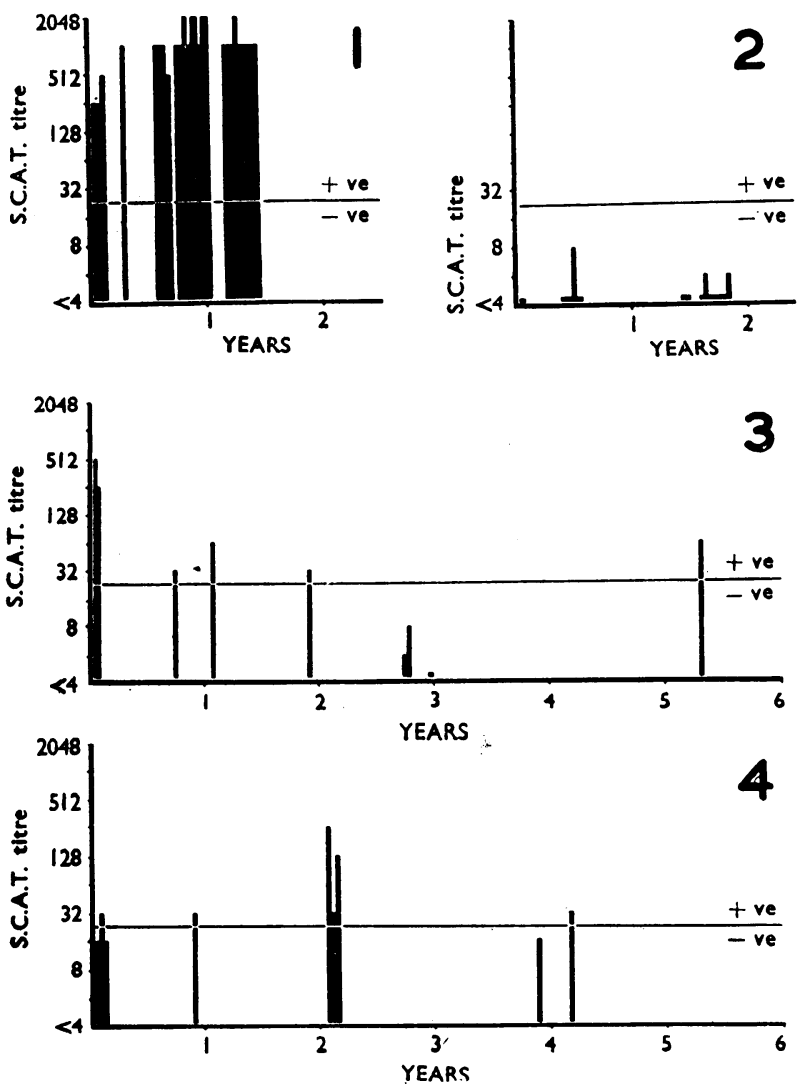

Fig. 1.-Histogram illustrating results of repeated sheep cell agglutination tests in four patients suffering from: (1) severe nodular rheumatoid arthritis; (2) spondylitis with severe peripheral joint involvement; (3) and (4) rheumatoid arthritis without nodules.

15 with rheumatoid arthritis in whom the test converted from positive to negative several months after the onset of complete remission of the disease process ; in four of these the test became positive again for a time during a recurrence of disease activity.

Many of the cases considered in this paper were not serially tested, so that in analysing our material we have mainly dealt with the results obtained at the first test in each case.

\section{Material}

Since 1949 all patients admitted to the rheumatism beds in the Manchester Royal Infirmary have had their sera tested routinely at weekly intervals during their stay in hospital. Patients attending a special spondylitis clinic have also had their sera tested routinely at least once, but since 1951 only selected patients attending other clinics have had their sera tested. Many tests have also been done on sera from in-patients under the care of other physicians and surgeons at the infirmary. Many of these patients had been seen in consultation by the staff of the rheumatism centre, and results from a few of these patients have been included to enlarge certain diagnostic groups that would otherwise have been rather small.
Sera collected during field surveys have also been studied. These were taken both from random samples of the general population (Kellgren and Lawrence, 1956) and from samples selected by clinical screening for arthritis (Miall et al., 1953, 1958 ; Miall, 1955).

\section{Results}

During the years $1952-7,790$ patients were admitted to the rheumatism beds of the infirmary. In Table I the results of the first in-patient S.C.A.T. are compared with

TABLE I.-Total In-patients, 1952-7: First In-patient S.C.A.T. Result, Original Diagnosis

\begin{tabular}{|c|c|c|c|c|}
\hline \multirow{2}{*}{\multicolumn{2}{|c|}{ Diagnosis }} & \multirow{2}{*}{ Total No. } & \multicolumn{2}{|c|}{ Positive } \\
\hline & & & No. & $\%$ \\
\hline $\begin{array}{l}\text { Definite rheumatoid arthritis } \\
\text { Probable ", ", } \\
\text { Juvenile ", } \\
\text { Diffuse collagen diseases " } \\
\text { Other arthritides .. } \\
\text { Bone diseases } . . \\
\text { Miscellaneous diseases } \quad .\end{array}$ & $\begin{array}{l}\ldots \\
\cdots \\
\cdots \\
\cdots \\
\cdots\end{array}$ & $\begin{array}{r}393 \\
41 \\
15 \\
78 \\
229 \\
18 \\
16\end{array}$ & $\begin{array}{r}340 \\
28 \\
6 \\
40 \\
23 \\
2 \\
2\end{array}$ & $\begin{array}{l}87 \\
68 \\
40 \\
51 \\
10 \\
11 \\
12 \cdot 5\end{array}$ \\
\hline Total & $\ldots$ & 790 & 441 & 56 \\
\hline
\end{tabular}

the clinical diagnoses recorded in each case before S.C.A.T. results became available. In arriving at this diagnosis $x$-ray films of the joints, and laboratory tests such as E.S.R., blood count, and occasionally other tests such as serum uric acid, L.E. cells, etc., were taken into account as well as the clinical features of the case.

In 393 patients the initial diagnosis was definite rheumatoid arthritis, and in $87 \%$ of these the S.C.A.T. was positive at the first test. In 41 patients rheumatoid arthritis was recorded as the diagnosis once in the outpatient clinic or on admission to the ward but some alternative diagnosis was recorded on the other occasion. These cases have been classed as probable rheumatoid arthritis, and positive tests were found in $68 \%$ of this group. Patients in whom polyarthritis began before the age of 15 years are classed as juvenile rheumatoid arthritis. Although some of them were young adults at the time of testing, only $40 \%$ of this small group had positive tests. This lower proportion of positive tests in juvenile rheumatoid arthritis has been observed by others, and indeed our figure of $40 \%$ is remarkably close to the $38 \%$ quoted by Ziff (1957) in. 69 cases collected from the literature.

The term "diffuse connective-tissue diseases" is used to indicate conditions such as systemic lupus erythematosus, systemic sclerosis, and polyarteritis nodosa, and it will be seen that positive tests were found in $51 \%$ of the 78 patients in this category. 229 patients were recorded as suffering from other forms of arthritis, and of these only $10 \%$ gave positive tests. There was a small group of 18 patients with various metabolic diseases of bone. The two patients who had positive tests in this group were suffering from malacia due to familial vitamin $D$ resistance and Paget's disease respectively. Finally there were 16 patients with miscellaneous non-articular diseases, amongst whom there were two positive tests.

In Table II are shown the results obtained during the period 1949-50. At this time all out-patients were tested routinely, and some $90 \%$ of the cases shown in this table were in fact seen only as out-patients. There is another important difference in that prior to 1951 our working definition for rheumatoid arthritis included all inflammatory polyarthritis for which no other cause could be demonstrated. In 1951 our working definition 
TARLE II.-Mainly Out-patients, 1949-50: First S.C.A.T. Result, Original Diagnosis

\begin{tabular}{|c|c|c|c|c|}
\hline \multirow{2}{*}{\multicolumn{2}{|c|}{ Diagnosis }} & \multirow{3}{*}{$\begin{array}{c}\text { Total No. } \\
642 \\
23 \\
941 \\
26 \\
291\end{array}$} & \multicolumn{2}{|c|}{ Positive } \\
\hline & & & No. & $\%$ \\
\hline $\begin{array}{l}\text { Rheumatoid arthritis } \\
\text { Diffuse collagen diseases } \\
\text { Other arthritides ... } \\
\text { Bone diseases } \\
\text { Miscellaneous diseases }\end{array}$ & $\begin{array}{l}\cdots \\
\therefore \\
\therefore \\
\ldots\end{array}$ & & $\begin{array}{r}327 \\
6 \\
45 \\
0 \\
4\end{array}$ & $\begin{array}{r}51 \\
26 \\
5 \\
0 \\
1\end{array}$ \\
\hline Total & .. & 1,923 & 382 & 20 \\
\hline
\end{tabular}

of rheumatoid arthritis was changed to include only polyarthritis which might be expected to be associated with a positive S.C.A.T. (Kellgren, 1952). Amongst the patients who were seen only as out-patients there were naturally many with relatively trivia! disease in whom the diagnosis was also less certain, and this together with the change in our diagnostic criteria probably accounts for the striking difference between the results in Tables I and II. The figures shown in Table II refer to the results of the S.C.A.T. read at 18 hours, as do all other results in this paper. They therefore differ slightly from the results of the test read at one hour that were published previously (Ball, 1952). It is, however, interesting to note that amongst the patients with rheumatoid arthritis tested during 1949-50 there were 96 with subcutaneous nodules and that $80(83 \%)$ of these were positive in the 18-hours test.

\section{Rheumatoid Arthritis}

Further details of the 393 patients with definite rheumatoid arthritis admitted to the wards during 1952-7 are shown in Table III. Subcutaneous nodules were recorded as present in $39 \%$ of these cases, and a positive S.C.A.T. was obtained in $100 \%$ of the 62 males and $92 \%$ of the 91 females with nodules. This confirms

TABLE III.-Definite Rheumatoid Arthritis: In-patient S.C.A.T. Results, 1952-7

\begin{tabular}{|c|c|c|c|c|c|c|c|c|c|}
\hline \multirow{3}{*}{ Nodules } & \multicolumn{3}{|c|}{ Males } & \multicolumn{3}{|c|}{ Fomales } & \multicolumn{3}{|c|}{ Both Sexes } \\
\hline & \multirow{2}{*}{$\begin{array}{c}\text { Total } \\
\text { No. }\end{array}$} & \multicolumn{2}{|c|}{ Positive } & \multirow{2}{*}{$\begin{array}{c}\text { Total } \\
\text { No. }\end{array}$} & \multicolumn{2}{|c|}{ Positive } & \multirow{2}{*}{$\begin{array}{l}\text { Total } \\
\text { No. }\end{array}$} & \multicolumn{2}{|c|}{ Positive } \\
\hline & & No. $\mid$ & $\%$ & & No. & $\%$ & & No. & $\%$ \\
\hline \multicolumn{10}{|c|}{ Original Diagnosis-First Test-Any Duration } \\
\hline \multirow{2}{*}{$\begin{array}{l}\text { Nodular } \\
\text { Non- } \\
\text { nodular }\end{array}$} & 62 & 62 & 100 & 91 & 84 & 92 & 153 & 146 & 95 \\
\hline & 87 & 73 & 84 & 153 & 121 & 78 & 240 & 194 & 81 \\
\hline Total & 149 & 135 & 90 & 244 & 205 & 84 & 393 & 340 & 87 \\
\hline \multicolumn{10}{|c|}{ Original Diagnosis-First Test-Duration under 1 Year Only } \\
\hline \multirow{2}{*}{$\begin{array}{l}\text { Nodular } \\
\text { Non- } \\
\text { nodular }\end{array}$} & 7 & 7 & 100 & 7 & 5 & 71 & 14 & 12 & 86 \\
\hline & 22 & 14 & 64 & 28 & 19 & 68 & 50 & 33 & 66 \\
\hline Total & 29 & 21 & 72 & 35 & 24 & 69 & 64 & 45 & 70 \\
\hline \multicolumn{10}{|c|}{ Revised Diagnosis-Highest Test-Any Duration } \\
\hline \multirow{2}{*}{$\begin{array}{l}\text { Nodular } \\
\text { Non- } \\
\text { nodular }\end{array}$} & 62 & 62 & 100 & 90 & 87 & 97 & 152 & 149 & 98 \\
\hline & 83 & 77 & 93 & 147 & 130 & 88 & 230 & 207 & 90 \\
\hline Total & 145 & 139 & 96 & 237 & 217 & 92 & 382 & 356 & 93 \\
\hline
\end{tabular}

our earlier observation of the close association between the rheumatoid serum factor and the necrobiotic rheumatoid nodule.

In 64 patients the disease was of less than one year's duration on admission to the ward. Nodules were present in 14 of these early cases and the S.C.A.T. was positive in $45(70 \%)$. In such early cases the diagnosis is necessarily less certain in some instances and as a result of subsequent developments can occasionally be shown to have been incorrect.
All the in-patients in whom a diagnosis of rheumatoid arthritis had been recorded but whose sera gave persistently negative tests were reviewed in a follow-up study by Dixon (1958). At this follow-up examination the original diagnosis of rheumatoid arthritis was shown to have been incorrect in 11 of the patients in this series. For instance, one woman with polyarthritis and nodules was later shown to be suffering from reticulohistiocytosis, and two other patients had developed psoriasis.

If such cases are excluded and the highest titre recorded is taken instead of the results of the first test, the proportion of positive tests in our definite cases of rheumatoid arthritis becomes $96 \%$ for males and $92 \%$ for females, a proportion which compares well with other published results using the same test or modifications of it (Heller et al., 1949 ; Pike et al., 1950 ; Hobson and Gorrill, 1952; Svartz and Schlossmann, 1952 ; de Forest et al., 1956), or other agglutinating systems (Heller et al., 1952 ; Svartz and Schlossmann, 1954 ; Jacobson et al., 1956; Ziff et al., 1956; Hess, 1956; Plotz and Singer, 1956; Craig et al., 1957; Singer and Plotz, 1958).

\section{Diffuse Connective-Tissue Diseases}

Our findings in this group are shown in Table IV, which includes a few patients seen only as out-patients

TABLE IV.-Diffuse Connective-Tissue and Vascular Diseases: In-patients and Out-patients, 1949-57. First S.C.A.T. Result -Original Diagnosis

\begin{tabular}{|c|c|c|c|c|c|c|}
\hline \multirow[t]{2}{*}{ Diagnosis } & \multirow{2}{*}{$\begin{array}{l}\text { Total } \\
\text { No. }\end{array}$} & \multicolumn{2}{|c|}{$\begin{array}{l}\text { S.C.A.T. } \\
\text { Positive }\end{array}$} & \multirow{2}{*}{$\begin{array}{c}\text { Mean } \\
\text { Age }\end{array}$} & \multicolumn{2}{|c|}{ Females } \\
\hline & & No. & $\%$ & & No. & $\%$ \\
\hline $\begin{array}{l}\text { Systemic lupus erythematosus .. } \\
\text { Systemic sclorosis and sclero- } \\
\text { derma } . . . \\
\text { Digital endarteropathy } \\
\text { Dermatomyositis } \\
\text { Polyarteritis nodosa } \\
\text { R.A. }\end{array}$ & $\begin{array}{l}41 \\
39 \\
25 \\
16 \\
11\end{array}$ & $\begin{array}{r}17 \\
16 \\
11 \\
2\end{array}$ & $\begin{array}{r}41 \\
41 \\
44 \\
13 \\
0\end{array}$ & $\begin{array}{l}38 \\
40 \\
46 \\
34 \\
36\end{array}$ & $\begin{array}{r}36 \\
32 \\
22 \\
12 \\
6\end{array}$ & $\begin{array}{l}88 \\
82 \\
88 \\
75 \\
55\end{array}$ \\
\hline Polyarteritis nodosa with R.A. & 4 & 3 & 75 & 52 & 1 & 25 \\
\hline
\end{tabular}

and also those seen in consultation with other physicians as well as the patients listed in Tables I and II.

Systemic Lupus Erythematosus.-Sera from 41 definite cases were tested, and $17(41 \%)$ of them gave a positive S.C.A.T. During the earlier years reliable tests for L.E. cells were not available to us, so that the diagnosis had to be based on clinical findings and the results of other laboratory tests. Of 16 later cases in which L.E. cells were found, eight gave positive tests. Among those in which the S.C.A.T. was positive, articular and/or peripheral vascular lesions were prominent, whereas in patients without this lesion, such as those in whom the disease affected mainly the skin and kidneys or other viscera, the S.C.A.T. was often negative.

Systemic Sclerosis.-Positive tests were obtained in $16(41 \%)$ of 39 cases. As in lupus erythematosus, high agglutinating titres tended to be associated with vascular and articular lesions, and negative tests were found in patients who only had scleroderma.

Digital Endarteropathy.-This group of patients consisted predominantly of adult females who developed rapid occlusion of the digital and other arteries associated with mild constitutional illness at the onset. They had severe Raynaud's phenomenon and nutritional lesions of the finger pulps, but they had no diffuse sclerosis and no articular lesions. Most of these patients came to us from the neurovascular surgical clinic, and some patients of this type were referred to by Jepson 
(1951) as examples of a form of Raynaud's syndrome peculiar to middle-aged females. One of these patients with a positive S.C.A.T. died of right heart failure secondary to presumed pulmonary hypertension, and at necropsy arterial lesions of the type shown in Fig. 2 were found in both digital and pulmonary arteries. Wade and Ball (1957) have published details of three further cases of unexplained pulmonary hypertension associated with a positive S.C.A.T. Similar arterial lesions have been reported in patients with systemic

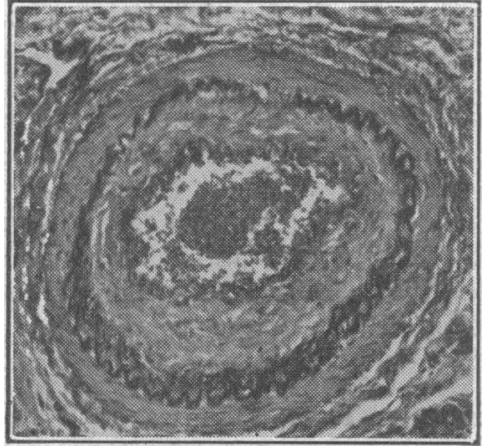

F1G. 2.-Section of artery showing concentric intimal fibro-elastosis, preservation of media and elastica, and absence of inflammatory cellular infiltration. $(\times 115$. sclerosis ( M asugi and Yä-Shu, 1938; Moore and Sheehan, 1952) and also in patients with rheumatoid arthritis (Bywaters, 1957). The S.C.A.T. wa s negative in all of 10 sera from patients with juvenile obliterative arteritis of Buerger's type kindly provided for us by the neurovascular clinic, and it is also usually negative in other vascular diseases. It

is therefore possible that the form of arteropathy shown in Fig. 2 as well as the rheumatoid nodule may be associated with positive S.C.A.T.

Dermatomyositis.-Only two positive results were obtained among 16 cases tested. Thus in dermatomyositis the S.C.A.T. was usually negative. In most instances the diagnosis presented no difficulty, but there were one or two patients in whom the alternative diagnosis of systemic lupus erythematosus was seriously considered at some stage, and this might account for the occasional positive test in this group.

Polyarteritis Nodosa.-The results of the S.C.A.T. in this group depend on whether the polyarteritis occurs independently or as a complication of severe rheumatoid arthritis (Ball, 1954). Amongst the 11 patients without rheumatoid arthritis in whom the diagnosis of polyarteritis nodosa was confirmed either by biopsy or by necropsy the S.C.A.T. was uniformly negative, so that this type of arterial disease is also not associated with a high agglutinating titre.

In summary it may be said that a positive S.C.A.T. was found in nearly half the patients with systemic lupus erythematosus or systemic sclerosis, and also in patients who had only the arterial lesions sometimes found in these and certain other syndromes; but in patients with dermatomyositis or polyarteritis nodosa and other miscellaneous arterial diseases the S.C.A.T. is rarely positive.

\section{Other Arthritides}

Our results in a variety of polyarthritic syndromes are presented in Table $V$. In nearly all these conditions the proportion of positive results in the S.C.A.T. is very low and does not differ from what may be expected in a random sample of the general population in the Northwest of England (see Table VII). Some comments on diagnostic definitions and the nature of the cases included in Table $\mathrm{V}$ are, however, required.
TABLE V.-Other Selected Diseases: In-patients and Out-patients, 1949-57. First S.C.A.T. Result-Original Diagnosis

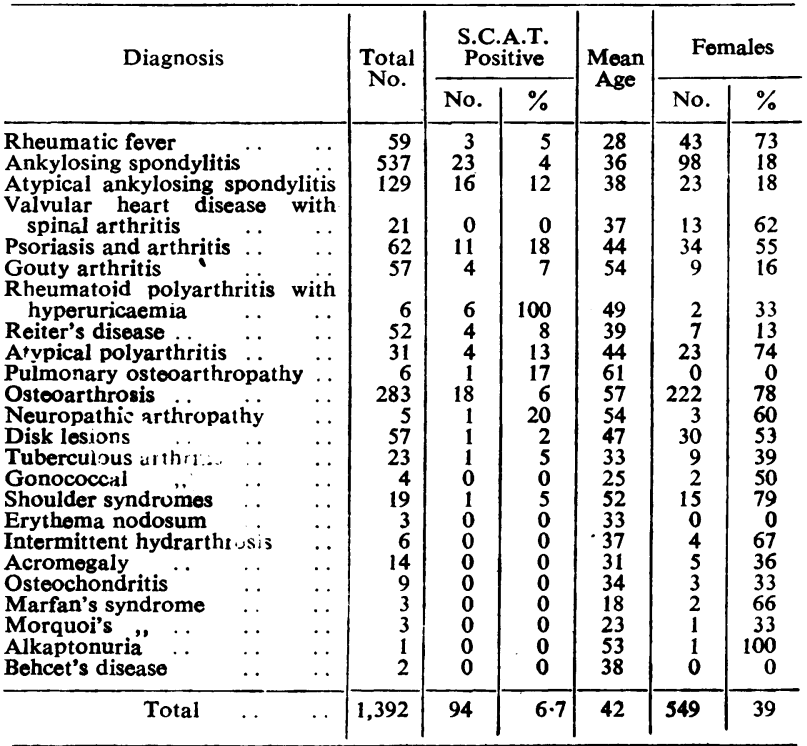

For rheumatic fever we have used the usual criteria, and our cases mainly represent patients with acute or subacute polysynovitis with active rheumatic heart disease. A high proportion of the patients were, however, adults, so that our group is not a truly representative sample of patients with rheumatic fever, which is predominantly a disease of childhood.

The 537 cases of ankylosing spondylitis represent typical cases (Sharp and Easson, 1954; Sharp, 1957). Amongst the 129 atypical cases there were a few that undoubtedly had rheumatoid arthritis with major spinal involvement, and in some of these cases the correct diagnosis has become apparent in later years ; but these have been included as spondylitis, since in Table $\mathrm{V}$ the original diagnosis is being compared with the results of the first S.C.A.T. performed. A detailed analysis of limb-joint involvement in relation to the S.C.A.T. has been carried out by Sharp for the patients seen by him in the spondylitis clinic during the years 1952-3. This is shown in Table VI. In this analysis the highest titre

TaBLE VI.-Spondylitis Series, 1952-3

\begin{tabular}{|c|c|c|c|c|c|c|c|}
\hline \multirow{2}{*}{$\begin{array}{l}\text { S.C.A.T. } \\
\text { Result and Limb } \\
\text { Joints Involved }\end{array}$} & \multicolumn{3}{|c|}{ Typical } & \multicolumn{3}{|c|}{ Atypical } & \multirow{2}{*}{ Total } \\
\hline & $\mathbf{M}$ & $\mathbf{F}$ & Total & $\mathbf{M}$ & $\mathbf{F}$ & Total & \\
\hline $\begin{array}{l}\text { S.C.A.T positive } \\
\text { Limb joints involved } \\
\text { * Peripheral limb joints } \\
\text { involved } \quad .\end{array}$ & $\begin{array}{l}5 \\
3 \\
2\end{array}$ & $\begin{array}{l}4 \\
1 \\
0\end{array}$ & $\begin{array}{l}9 \\
4 \\
2\end{array}$ & $\begin{array}{l}6 \\
6 \\
4\end{array}$ & $\begin{array}{l}2 \\
1 \\
1\end{array}$ & $\begin{array}{l}8 \\
7 \\
5\end{array}$ & $\begin{array}{r}17 \\
11 \\
7\end{array}$ \\
\hline $\begin{array}{l}\text { S.C.A.T. negative } \\
\text { Limb joints involved } \\
\text { * Peripheral limb joints } \\
\text { involved } \quad .\end{array}$ & $\begin{array}{r}108 \\
67 \\
30\end{array}$ & $\begin{array}{r}15 \\
9 \\
5\end{array}$ & $\begin{array}{r}123 \\
76 \\
35\end{array}$ & $\begin{array}{l}31 \\
23 \\
21\end{array}$ & $\begin{array}{l}1 \\
1 \\
1\end{array}$ & $\begin{array}{l}32 \\
24 \\
22\end{array}$ & $\begin{array}{r}155 \\
100 \\
57\end{array}$ \\
\hline Total patients .. & 113 & 19 & 132 & 37 & 3 & 40 & 172 \\
\hline
\end{tabular}

* Knees and elbows and all joints distal to these wore classed as peripheral.

recorded in multiple tests was used instead of the results of the first test. It will be seen that some form of limbjoint involvement was common even in the typical cases but that peripheral joint involvement was observed only in some $31 \%$ of the typical cases, though it was the rule in atypical cases. Only 2 out of 37 typical cases with peripheral joint involvement and only 5 out of 27 atypical cases with peripheral joint involvement had positive tests, so that a high agglutinating titre is not 
specially associated with peripheral joint involvement as such but appears to be related more to the type of joint involvement. In this respect our findings agree with those of other workers as reported by Ziff (1957).

Progressive valvular heart disease with spinal arthritis is a category that requires further definition. Patients in this group had recurrent episodes of polyarthritis affecting both limb joints and spine, with a marked tendency to spinal ankylosis. The heart lesions, which were predominantly aortic, progressed with each episode of arthritis. Three patients with this syndrome also had all the features of recurrent Reiter's disease, and have been included under that head, but in the 21 remaining cases there was no clue to the nature of the disease process. In past publications from this centre these patients have been classed as examples of chronic rheumatic fever (Thomas, 1955 ; Sharp, 1957), but the detailed anatomical studies of similar cases reported by Clark et al. (1957) make this hypothesis no longer tenable. On the other hand, the uniformly negative results of the S.C.A.T. in this group are strong evidence against their being cases of rheumatoid disease with cardiac involvement. We have therefore used the noncommittal descriptive term of progressive valvular heart disease with spinal arthritis.

The category of psoriasis and arthritis contains all our patients with inflammatory and erosive polyarthritis who also were recorded as having psoriasis and whose sera were tested. Two of these cases also had nodules, and a small number of the patients in this group appeared to have typical rheumatoid arthritis, but in the great majority the arthritis had distinctive characteristics and the S.C.A.T. was negative. Many patients with typical psoriatic arthropathy were not tested, so that there is an excess of patients with possible rheumatoid arthritis amongst the 62 that were tested. If we allow for this selection, our findings are in general agreement with those of Wright (1957) and other workers as reported by Ziff (1957), and in practice we distinguish psoriatic arthropathy from rheumatoid arthritis, a distinction we have found useful in the management of individual patients.

The majority of our 57 cases of gouty arthritis had severe gout with chronic joint involvement, and tophi, and all had hyperuricaemia of over $6 \mathrm{mg} . / 100 \mathrm{ml}$. In this group there were only four positive tests, which is in agreement with the findings of others (Ziff, 1957).

There were, however, six patients with typical rheumatoid arthritis in whom hyperuricaemia was an unexpected laboratory finding. In these cases synovial biopsy and other detailed investigations were carried out to establish the correct diagnosis. The S.C.A.T. was positive in all six, which suggests that hyperuricaemia as such does not inhibit this reaction.

The 52 cases of Reiter's disease were all definite cases. Although the majority were recurrent or chronic cases, the S.C.A.T. was positive in only four.

The category of atypical polyarthritis has been used for patients with chronic inflammatory polyarthritis affecting mainly the larger limb joints and spine but in whom there were none of the radiological signs of spondylitis. The nature of the arthritis in these patients is at present obscure ; but the S.C.A.T. is rarely positive in this type of case, so that we do not classify them as rheumatoid arthritis.

The remaining diagnostic categories need no comment.
In summary our findings agree very closely with those of other workers, and the low proportion of positive tests in most of the polyarthritic conditions shown in Table III is strong evidence against these conditions being varieties of rheumatoid disease as we define it.

\section{Uveitis}

Uveitis has often been regarded as a feature of rheumatoid disease. In adults uveitis is an important feature of both spondylitis and Reiter's disease but is rarely seen in nodular rheumatoid arthritis (Stanworth and Sharp, 1956).

The S.C.A.T. was performed in 190 patients with uveitis attending the Manchester Royal Eye Hospital. Positive results were obtained in only $10(5 \%)$, and 6 of these had clinical evidence of rheumatoid arthritis. There does not therefore appear to be any association between uveitis and the rheumatoid serum factor.

\section{Population Studies : Random Samples}

In the course of epidemiological studies of rheumatoid disease the S.C.A.T. has been determined in sera from a 1 in 10 random sample of all individuals in the age group 55-64 years in the Lancashire town of Leigh, which has a population of approximately 48,000 . These individuals also had a comprehensive clinical and radiological examination (Kellgren and Lawrence, 1956). The proportion of sera showing agglutination at each dilution is shown in Fig. 3, and it will be seen that there

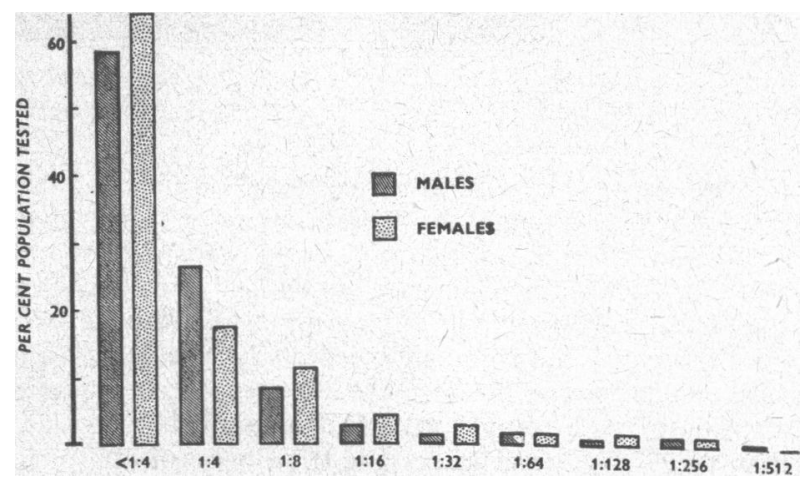

FIG. 3.-Distribution of sheep cell agglutinating titres in sera from a random sample of an urban population aged 55-64 years. The sample contained 163 males and 187 females. (Reproduced from Ann. rheum. Dis., 1956, 15,3.)

TABLE VII.-Clinical and Radiological Evidence of Rheumatoid Arthritis in 19 Individuals With a Positive S.C.A.T. From Random Sample of Population Aged 55-64 Evidence of Rheumatoid Arthritis

Definite clinical and radiological rheumatoid arthritis ", radiological rheumatoid arthritis only Nossible clinical rheumatoid arthritis
No rhmatoid arthritis recorded No. of Individuals

is remarkably little difference between the two sexes. Of the 350 individuals tested, 163 were males, $8(5 \%)$ with positive tests, and 187 females, $11(6 \%)$ with positive tests. The clinical and radiological findings in the 19 individuals with positive tests are shown in Table VII. Of these, eight had definite clinical rheumatoid arthritis, a further four had clinical symptoms or signs suggestive of rheumatoid arthritis, but in the remaining seven no clinical evidence of rheumatoid arthritis was recorded. However, in two of these individuals definite radiological signs of rheumatoid arthritis were present-in the feet in one case and in the cervical spine in the other. In another 
small random sample from South Wales two further individuals were encountered with a positive S.C.A.T. in whom the only signs of rheumatoid arthritis were radiological changes in the cervical spine. This finding led to a detailed investigation of the radiological and pathological features of rheumatoid arthritis of the cervical spine in adults (Ball, 1958 ; Sharp, Purser, and Lawrence, 1958).

In established cases of rheumatoid arthritis being treated in hospital the following radiological appearances were characteristically found: narrowing of multiple disks, especially the upper ones, a tendency to subluxation, and a lack of accompanying osteophytosis (Fig. 4). In a random population sample of 428

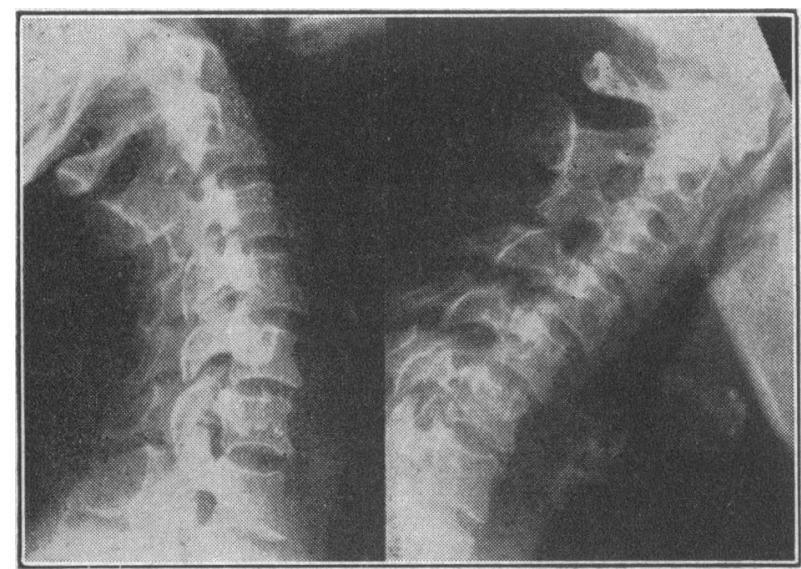

FIG. 4.-Radiograph of cervical spine in flexion and extension showing multiple subluxations. Woman aged 51 with nodular rheumatoid arthritis of five years' duration; S.C.A.T. 1:512.

individuals aged 55-64 radiological appearances of this type showed a significant association with positive results in the S.C.A.T., but they were often not associated with other clinically recognizable evidence of rheumatoid arthritis. In clinical practice we have also been struck by the frequency, especially in elderly men, with which severe radiological changes of rheumatoid arthritis may be found in the feet of patients who state that they have never experienced pain or disability in the feet. It would thus appear that a proportion of positive tests in the S.C.A.T. may be associated with rheumatoid changes in the joints which may be either symptomless or of such a nature that they would not be generally recognized as rheumatoid by current criteria. Apparently false-positive results in the S.C.A.T. should therefore be accepted with reserve, at least in the 55-64 age group. The details of the five individuals from the Leigh sample with apparently false-positive tests are set out in Table VIII, from which it will be seen that at least three of them had significant signs of joint disease which may well have been rheumatoid in nature though they were not so regarded at the time of the survey.

The study in Leigh has been extended by Lawrence to a 1 in 30 sample of all individuals of over 25 years of age and, although the complete material has not yet been analysed, the results of the S.C.A.T. are shown in Table IX. From this it will be seen that positive tests were obtained in $5.7 \%$ of the 1,165 individuals tested, the proportion of positive tests being somewhat higher at certain ages and lower at others. In the younger age groups clinical and radiological evidence of rheumatoid arthritis will certainly have a lower prevalence, which raises the question of the significance of these positive tests in the younger individuals.

In a study of the relatives of propositi with positive S.C.A.T. obtained from the random sample of Leigh, Lawrence and Ball (1958) found 19 positive tests amongst 94 available blood relatives, a proportion of $20 \%$, which is far greater than the $5.7 \%$ found in the population as a whole. Similar results have been reported by Ziff et al. (1958), who found positive inhibition tests in $20 \%$ of 140 relatives of 46 propositi with rheumatoid arthritis, although only two positive results were obtained with the direct euglobulin agglutination test. The rheumatoid serum factor would therefore appear to show a significant degree of familial aggregation. No such increased prevalence of positive tests has so far been observed in a small sample of spouses tested. Thus a positive S.C.A.T. may well be an index of some inherited biochemical characteristic which predisposes the individual concerned to certain types of disease, and a high prevalence of both clinical

TABLE IX.-S.C.A.T. Results by Sex and Age Group in 1 in 30 Random Sample of the Adult Population of Leigh

\begin{tabular}{|c|c|c|c|c|c|c|c|c|c|c|c|}
\hline \multirow{3}{*}{$\begin{array}{c}\text { Age } \\
\text { Group }\end{array}$} & & \multicolumn{5}{|c|}{ Males } & \multicolumn{5}{|c|}{ Females } \\
\hline & & \multirow[b]{2}{*}{ 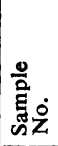 } & \multirow[b]{2}{*}{ 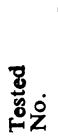 } & \multicolumn{3}{|c|}{ Positive } & \multirow[b]{2}{*}{ 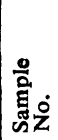 } & \multirow[b]{2}{*}{ 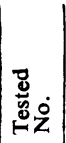 } & \multicolumn{3}{|c|}{ Positive } \\
\hline & & & & No. & 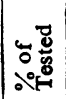 & 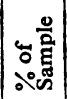 & & & No. & 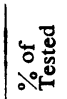 & 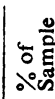 \\
\hline $\begin{array}{l}15-24 \\
25-34 \\
35-44 \\
45-54 \\
55-64 \\
65+\ldots \\
\text { Not stated }\end{array}$ & $\begin{array}{l}\because \\
\because \\
\because \\
\because \\
\therefore\end{array}$ & $\begin{array}{r}55 \\
131 \\
127 \\
169 \\
102 \\
91 \\
6\end{array}$ & $\begin{array}{r}48 \\
113 \\
103 \\
146 \\
88 \\
75 \\
-\end{array}$ & $\begin{array}{r}0 \\
5 \\
2 \\
9 \\
4 \\
11\end{array}$ & $\begin{array}{r}0 \\
4 \\
2 \\
6 \\
5 \\
15\end{array}$ & $\begin{array}{r}0 \\
4 \\
2 \\
5 \\
4 \\
12\end{array}$ & $\begin{array}{r}65 \\
115 \\
148 \\
171 \\
139 \\
115 \\
5\end{array}$ & \begin{tabular}{r|}
56 \\
98 \\
119 \\
140 \\
101 \\
78 \\
\end{tabular} & \begin{tabular}{|r}
2 \\
5 \\
4 \\
11 \\
6 \\
7
\end{tabular} & $\begin{array}{l}4 \\
5 \\
3 \\
8 \\
6 \\
9\end{array}$ & $\begin{array}{l}3 \\
4 \\
3 \\
6 \\
4 \\
6\end{array}$ \\
\hline Total & .. & 681 & 573 & 31 & 5.4 & $\overline{4.6}$ & 758 & 592 & 35 & $\overline{5.9}$ & 4.6 \\
\hline
\end{tabular}

TABLE VIII.-Features of Five Individuals from Random Sample Aged 55-64 with Positive S.C.A.T. in Whom No Evidence of Rheumatoid Arthritis was Recorded at the Time of Survey

\begin{tabular}{|c|c|c|c|c|c|c|c|c|c|c|}
\hline \multirow{3}{*}{ Case } & \multirow{3}{*}{\multicolumn{2}{|c|}{$\begin{array}{c}\text { Sex } \\
\text { and Age }\end{array}$}} & \multirow{3}{*}{ S.C.A.T. } & \multicolumn{4}{|c|}{ Radiological Findings } & \multirow{3}{*}{ Symptoms } & \multirow{3}{*}{$\begin{array}{l}\text { Clinical Signs of } \\
\text { Joint Disease }\end{array}$} & \multirow{3}{*}{ Clinical Diagnosis } \\
\hline & & & & \multicolumn{2}{|c|}{ Rheumatoid Arthritis } & \multicolumn{2}{|c|}{ Osteoarthrosis } & & & \\
\hline & & & & Grade & Site & Grade & Site & & & \\
\hline 190 & & 57 & $1 / 256$ & None & 一 & Slight & Hands, feet, & Lumbago one attack & Back, reduced curves, limited & Disk degeneration \\
\hline 215 & & 55 & $1 / 64$ & Doubtful & Feet & None & - & $\begin{array}{l}\text { Recurrent lumbago; } \\
\text { few days' pain in arms }\end{array}$ & $\begin{array}{l}\text { Crepitus in shoulders, limited } \\
\text { lumbar spine, vaso-spasm, }\end{array}$ & $\begin{array}{l}\text { Osteoarthrosis and disk } \\
\text { degeneration }\end{array}$ \\
\hline $\begin{array}{l}300 \\
333\end{array}$ & & $\begin{array}{l}60 \\
60\end{array}$ & $\begin{array}{l}1 / 32 \\
1 / 64\end{array}$ & $\begin{array}{l}\text { None } \\
\text { Doubtful }\end{array}$ & Hands & Slïht & Knees, spine & $\begin{array}{l}\text { None } \\
\text { After crush injury to } \\
\text { feet, } 5 \text { years' pains in } \\
\text { thumbs, knees, back, }\end{array}$ & $\begin{array}{l}\text { Contracture palmar fascia } \\
\text { Crepitus in knees, tender } \\
\text { thickening of lateral meta- } \\
\text { tarso-phalangeal joints }\end{array}$ & $\begin{array}{l}\text { Dupuytren's contracture } \\
\text { Osteoarthrosis }\end{array}$ \\
\hline 14 & & 62 & $1 / 128$ & None & - & ", & Hands, feet & None & $\begin{array}{l}\text { Heberden's nodes, hallux } \\
\text { rigidus, cervical, spine } \\
\text { limited }\end{array}$ & $"$ \\
\hline
\end{tabular}


and radiological signs of rheumatoid arthritis was in fact noted amongst the 94 relatives of propositi with a positive S.C.A.T. studied by Lawrence. There is also the possibility that the characteristic of which a positive S.C.A.T. may be an index may predispose the individual to other and as yet undefined disease, and further investigation of this possibility is urgently required.

\section{Population Studies : Screened Samples}

Sera from population samples characterized by certain clinical and/or radiological characteristics have also been investigated. These sera were collected by the staff of the Medical Research Council's Pneumoconiosis Research Unit in the course of epidemiological studies.

The first of these concerned an investigation of Caplan's syndrome (Miall et al., 1953) in which a positive S.C.A.T. and/or radiological signs of rheumatoid arthritis in films of the hands and feet were used as diagnostic criteria for confirming the diagnosis of rheumatoid arthritis.

As a result of further studies of Caplan's syndrome (Ball, 1955) and our experience with several cases of obscure lung disease we incline to the view that certain lung lesions may be associated with a positive S.C.A.T. -another possibility that requires further investigation. Miall (1955) and Miall et al. (1958) have also studied the general population of the Rhondda Fach, which is a mining valley, and the Vale of Glamorgan, which is a neighbouring agricultural district in South Wales. The whole population was screened for clinical rheumatoid arthritis, using the classical definition of inflammatory polyarthritis of the peripheral joints. In the Rhondda only those individuals who on clinical grounds were considered to have definite or probable rheumatoid arthritis were further investigated radiologically and serologically, but in the Vale even the most doubtful cases were investigated. The S.C.A.T. results in these samples are included in Table $\mathbf{X}$, which is mainly designed to illustrate the effect of the level of clinical diagnosis upon the proportion of positive results in the S.C.A.T. Possible geographic differences in prevalence between Lancashire and South Wales and between urban and rural populations are under investigation, but they are unlikely to invalidate the main findings, which are that the proportion of positive results obtained in any sample of individuals stated to be suffering from rheumatoid arthritis is largely determined by the diagnostic criteria used and the severity of the disease.

The proportion of positive tests in the Rhondda sample and in our own predominantly out-patient material for $1949-50$ is very similar, and shows a striking sex difference which is less apparent in hospital inpatients and is altogether absent in the random population sample. At this level of diagnosis and severity there are therefore many women with peripheral polyarthritis which resembles rheumatoid arthritis clinically but which is not associated with a positive S.C.A.T. The nature of this form of polyarthritis is still obscure, but Table XI shows the relationship

TABLE XI.-S.C.A.T. Results in Relation to Radiological Generalized Osteoarthrosis in Rhondda Females Clinically Graded as Probable or Definite Rheumatoids

\begin{tabular}{|c|c|c|c|c|c|}
\hline \multirow{3}{*}{$\begin{array}{l}\text { S.C.A.T. } \\
\text { Result and Titre }\end{array}$} & \multirow{3}{*}{$\begin{array}{l}\text { Total } \\
\text { No. }\end{array}$} & \multicolumn{4}{|c|}{$\begin{array}{c}\text { With Radiological Generalized } \\
\text { Ostooarthrosis } \\
\end{array}$} \\
\hline & & \multicolumn{2}{|c|}{ Minimal to Severe } & \multicolumn{2}{|c|}{ Moderate to Severe } \\
\hline & & No. & $\%$ & No. & $\%$ \\
\hline $\begin{array}{l}\text { Positive } 1: 256 \text { and higher } \\
\text { Negative } 1:<4 \text { to } 1: 128 \ldots \\
\text { No } 1: 16\end{array}$ & $\begin{array}{l}14 \\
24 \\
93\end{array}$ & $\begin{array}{l}0 \\
11 \\
51\end{array}$ & $\begin{array}{r}0 \\
46 \\
55\end{array}$ & $\begin{array}{r}0 \\
5 \\
24\end{array}$ & $\begin{array}{r}0 \\
21 \\
26\end{array}$ \\
\hline Total & 131 & 62 & 47 & 29 & 22 \\
\hline
\end{tabular}

between the S.C.A.T. and radiological gradings of generalized osteoarthrosis in the hand films of the females from the Rhondda who on clinical examination were considered to be suffering from probable or definite rheumatoid arthritis. Of the 38 women with positive tests who were $x$-rayed, only $11(29 \%)$ had definite osteoarthrosis, whereas of the 93 with negative tests $51(55 \%)$ had definite radiological signs of osteoarthrosis. Thus this condition may account for a substantial proportion of peripheral joint disease in middle-aged women which may be classed as possibly rheumatoid in nature as a result of the type of clinical examination that can be carried out in a field survey or in a busy out-patient clinic ; our experience of hospital practice since 1952 is in agreement with this, since most of the patients with generalized osteoarthrosis we see in hospital are referred to us as cases of rheumatoid arthritis. This question is discussed more fully elsewhere (Miall 'et al., 1958).

There may also be other forms of inflammatory polyarthritis in women which have not as yet been characterized. In this connexion it is interesting to note that certain forms of polyarthritis associated with negative tests such as spondylitis and Reiter's disease are at present almost exclusively recognized in males, and it may be that these conditions do in fact also affect females, but in a form which we are at present unable to distinguish on clinical grounds from rheumatoid arthritis.

\section{Conclusions}

What can be learned about the clinical significance of the S.C.A.T. from the data presented in this paper?

From the population studies it would appear that the serum factor responsible for agglutination in this system exists in some $5 \%$ of the adult urban population in Lancashire, the proportion of positive tests being somewhat higher in old age and somewhat lower in the younger age groups. In this population positive results

TABle X.-S.C.A.T. Results at Different Levels of Clinical Diagnosis

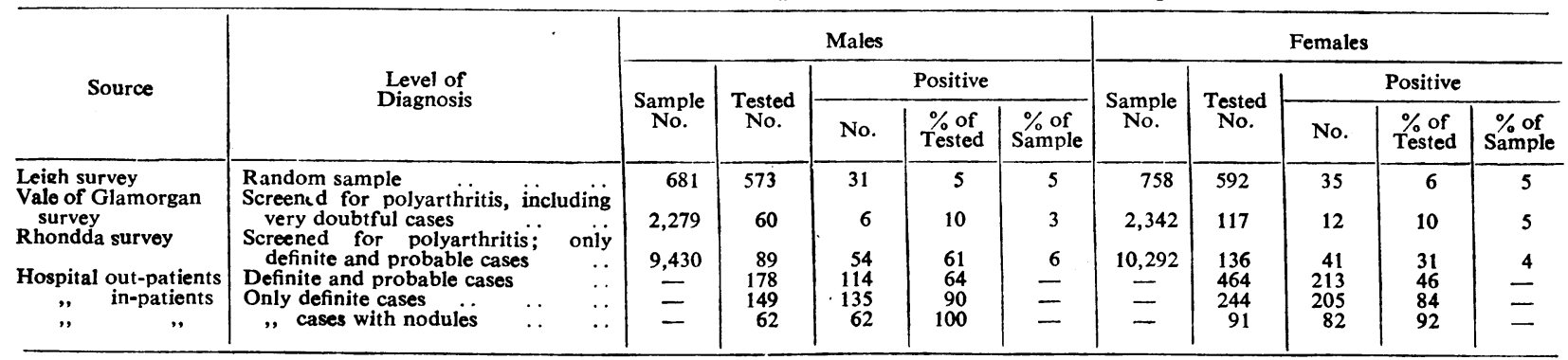


in the S.C.A.T. show a significant degree of familial aggregation, being found in some $20 \%$ of blood relatives of propositi with positive tests. The presence of a positive S.C.A.T. may therefore be genetically determined. If this is so, it may represent an index of some inherited metabolic defect which predisposes the individual concerned to develop certain pathological lesions which from this point of view should be described as features of rheumatoid disease.

It is, however, likely that the disease process itself contributes to the amount of rheumatoid factor found in the serum at any given time. Environmental factors precipitating disease activity are probably important and might even on occasion produce articular disease and a positive S.C.A.T. in patients not genetically predisposed, so that the problem may be very complicated and much more work is required before the whole story can be unravelled. Nevertheless the idea of an inherited predisposing metabolic defect provides a most useful working hypothesis for the purpose of further studies.

From the study of patients in hospital it is clear that a positive S.C.A.T. is very closely associated with the rheumatoid necrobiotic nodule and a certain type of erosive polyarthritis of the limb joints and upper spine. On the other hand, there are clearly many forms of erosive polyarthritis which are not associated with a positive S.C.A.T., and these we would by definition exclude from our concept of rheumatoid disease.

High titres in the S.C.A.T. may also be associated with certain vascular lesions which may occur independently or as a part of diffuse connective-tissue diseases such as systemic lupus erythematosus and systemic sclerosis. These conditions are, however, relatively uncommon, and their relationship to the rheumatoid serum. factor and the more common articular and nodular manifestations of rheumatoid disease requires further investigation. There may also be other as yet undefined lesions which might be brought to light by a study of individuals with a positive S.C.A.T. and/or their relatives.

The study of rheumatic diseases has been severely hampered by the lack of precise definition and aetiological classification. Certain notable advances were made in the past, such as the distinction between inflammatory and degenerative joint disease, the definition of gout in terms of hyperuricaemia and an inherited or acquired disorder of uric acid metabolism, and the demonstration of the role of streptococcal infection in rheumatic fever. Perhaps a definition of rheumatoid disease in terms of the rheumatoid serum factor may prove equally valuable.

\section{Summary}

Since 1949 the rheumatoid serum factor has been estimated by the same technique using a sensitized sheep cell agglutinating system (S.C.A.T.). This test has been done routinely on sera from all patients admitted to the rheumatism beds of the Manchester Royal Infirmary and from selected groups of out-patients. The test has also been carried out on sera collected during surveys of both random and screened samples of the general population.

A positive result in the S.C.A.T. was found in $93 \%$ of 382 in-patients with rheumatoid arthritis in whom great care was taken to establish the correctness of the diagnosis. Of these patients 152 had subcutaneous nodules, and $98 \%$ of these cases had positive tests Positive tests were obtained in $70 \%$ of 64 patients with rheumatoid arthritis of less than one year's duration and in $68 \%$ of 41 patients with rheumatoid arthritis in whom an alternative diagnosis was recorded at some stage of their care in hospital. In both these groups the diagnosis was less certain, and this is reflected in the lower proportion of positive tests.

Some $40 \%$ of positive tests were found in patients with systemic lupus erythematosus, with systemic sclerosis, and also in patients with a form of endarteropathy affecting digital or pulmonary vessels ; but the S.C.A.T. was usually negative in other forms of arterial disease and in dermatomyositis.

A positive S.C.A.T. was found in only $6.7 \%$ of sera from 1,392 patients attending hospital for other forms of arthritis, though many of these patients, such as those with atypical spondylitis, Reiter's disease, and psoriatic arthropathy, had severe inflammatory erosive polyarthritis which resembled rheumatoid arthritis in many respects.

A positive S.C.A.T. was found in $5.7 \%$ of 1,165 sera from a random sample of the adult population of a Lancashire town. In this population positive tests were fairly evenly distributed between the sexes and throughout the age groups tested although the proportion of positive tests was somewhat higher in the older and lower in the younger subjects. Positive tests showed a substantial degree of familial aggregation, being found in $20 \%$ of 94 blood relatives of propositi with positive tests.

These findings are discussed, and it is concluded that the rheumatoid serum factor may represent an index of some inherited metabolic characteristic which predisposes the individual to rheumatoid arthritis and certain other forms of disease that may not yet be fully defined. Conversely many other forms of inflammatory erosive polyarthritis appear to be unrelated to this characteristic.

We wish to thank Dr. W. E. Miall, of the Medical Research Council's Pneumoconiosis Research Unit, and Dr. J. S. Lawrence, of the Empire Rheumatism Council's Field Unit, for providing us with sera from population samples. We are also grateful to Professor A. M. Boyd and the other surgeons and physicians of the Manchester Royal Infirmary who provided us with sera from patients with vascular and other non-rheumatic diseases.

\section{REFERENCES}

Ball, J. (1950), Lancet, 2, 520.

(1952). Ann. rheum. Dis., 11, 97.

(1954). Abid., 13, 277.

(1955). Ibid., 14, 159.

(1958). Lancet, 1, 86.

Bozicevich, J., Bunim, J. J., Freund, J., and Ward, S. B. (1958). Proc. Soc. exp. Biol. (N.Y.), 97, 180

Bywaters, E. G. L. (1957). Ann. rheum. Dis., 16, 84.

Clark, W. S., Kulka, J. P., and Bauer, W. (1957). Amer. J. Med., 22, 580 Craig, H. W., Kerby, G. P., and Persons, E. L. (1957). J. Lab.

Dixon, A. St. J. (1958). Ann. rheum. Dis., 17, 252.

Epstein, W. Johnson, A. M., and Ragan, C. (1956). Proc. Soc. exp. Biol. (N.Y.), $91,235$.

de Forest, G K., Mucci, M. B., and Boisvert, P. L. (1956). Amer. J. Med., 2i, 897.

(1958). Arthr. and Rheum., 1, 387.

. C., Kunkel, H. G., Müller-Eberhard, H. J., and Holman, H. R. (1957). Ann. rheum. Dis., 16, 315.

Greenbury, C. L. (1956). Lancet, 2, 644.

Heller, G., Jacobson, A. S., and Kolodny, M. H. (1949). Proc. Soc. exp. Biol. (N.Y.), 72, 316.

Jacobson, A. S., Kolodny, M. H., and Schuman, R. L. (1952). J. Immunol., 69, 27.

Hess, E. V. (1956). Brit. med. J., 1, 1426.

Hobson, D., and Gorrill, R. H. (1952). Lancet, 1, 389. 
Jacobson, A. S., Kammerer, W. H., Wolf, J., Epstein, W. V. and Heller, G. (1956). Amer. J. Med., 20, 490.

Jepson, R. P. (1951). Ann. Roy. Coll. Surg. Engl., 9, 35.

Kellgren, J. H. (1952). Brit. med. J., 1, 1093, 1152 .

and Lawrence, J. S. (1956). Ann. rheum. Dis., 15, 1.

Lawrence, J. S., and Bali, J. (1958). Ibid., 17, 160.

McEwen, C., Ziff, M., Carmel, P., DiTata, D., and Tanner, M. (1958). Arthr. and Rheum., 1, 481.

Masugi, M., and Yä-Shu (1938). Virchows Arch. path. Anat., $302,39$.

Miall, W. E. (1955). Ann. rheum. Dis., 14, 150.

- Ball, J., and Kellgren, J. H. (1958). Ibid., 17, 263

Caplan, A., Cochrane, A. L., Kilpatrick, G. S., and Oldham, P. D. (1953). Brit. med. J., 2, 1231

Moore, H. C., and Sheehan, H. L. (1952). Lancet, 1, 68.

Pike, R. M., Sulkin, S. E., and Coggeshall, H. C. (1950). Bact. Proc., 87.

Plotz, C. M., and Singer, J. M. (1956). Amer. J. Med., 21, 893.

Rose, H. M., Ragan, C., Pearce, E., and Lipman, M. O. (1948) Proc. Soc. exp. Biol.' (N.Y.), 68, 1 .

Sharp, J. (1957). Brit. med. J., 1, 975.

Sharp, Ja Easson, E. C. (1954). Ibid., 1, 619.

Purser, D. W., and Lawrence, J. S. (1958). Ann. rheum Dis., 17, 303. Singer, J. M., and Plotz, C. M. (1958). Arthr. and Rheum., 1,

Stanworth, A., and Sharp, J. (1956). Ann. rheum. Dis., 15, 140

Svartz, N., and Schlossmann, K. (1952). Acta med. scand., 142 420 .

(1954). Ibid., 149, 83.

Thomas, A. E. (1955). Ann. rheum. Dis., 14, 259.

Wager, O. (1950). Ann. Med. exp. Fenn., 28, Suppl. 8

Wade, G., and Ball, J. (1957). Quart. J. Med., 26, 83.

Wright, V. (1957). Brit. J. Derm., 69, 1 .

Ziff, M. (1957). J. chron. Dis., 5, 644 . Brown, P., Lospalluto, J., Badin, J., and McEwen, C. (1956). Amer. J. Med., 20, 500.

Schmid, F. R., Lewis, A. J., and Tanner, M. (1958). Arthr. and Rheum., 1, 392.

\section{TOTAL THORACIC SUPERVOLTAGE IRRADIATION FOLLOWED BY THE INTRAVENOUS INFUSION OF STORED AUTOGENOUS MARROW}

\author{
BY
}

\section{K. A. NEWTON, F.F.R., M.R.C.P.}

J. G. HUMBLE, C.V.O., M.R.C.S., L.R.C.P.

C. W. WILSON, M.Sc., Ph.D., F.Inst.P.

D. E. PEGG, M.B., B.S.

AND

\section{E. G. SKINNER, F.R.C.S.Ed.}

Westminster Hospital

The inevitable result of large-volume high-dosage radiotherapy is damage to bone marrow and a subsequent lowering of the circulating blood elements. This factor, combined with the adverse constitutional effects on the patient, has undoubtedly prevented the full exploitation of radiation in the disseminated radiosensitive tumours.

Many workers have described the severe and sometimes permanently damaging effects to marrow that can follow from a dosage of radiation well below that used by the radiotherapist in the treatment of cancer. Stewart (1958), in a study of 126 patients with ankylosing spondylitis, comments that $2,000 \mathrm{r}$ may render the bone marrow hypoplastic for years and that after 4,000 r there is no recovery in $50 \%$ even after several years. This substantiates the observation of Humble (1948), who has shown the profound effect on cellularity which can accrue from moderate dosage radiotherapy (Table I).

Kurnick et al. (1958) described the use of stored autogenous marrow to combat the haemopoietic
TABLE I.-Effect of Direct $X$-irradiation on Sternal Marrow After $2,000 r$ in 22 Days

\begin{tabular}{|c|c|c|c|}
\hline & & Before Irradiation & After Irradiation \\
\hline $\overrightarrow{\text { Total nucleated count }}$ & . & 56,000 per c.mm. & 9,200 per c.mm. \\
\hline $\begin{array}{l}\text { Myeloblasts } \\
\text { Promyelocytes } \\
\text { Myelocytes, neutrophil } \\
\text { Metamyelocytes \#", } \\
\text { Polymorphs, } \\
\text { Myelocytes, eosinöphil } \\
\text { Polymorphs, } \\
\text { Myelocytes, basophil } \\
\text { Polymorphs, ", }\end{array}$ & \begin{tabular}{ll|}
$\because$. & $\cdots$ \\
$\because$ & $\cdots$ \\
$\because$ & $\cdots$ \\
$\because$ & $\cdots$ \\
$\because$ & $\cdots$ \\
$\because$ & $\cdots$ \\
$\cdots$ & $\cdots$
\end{tabular} & $\begin{array}{l}0.4 \% \\
1.8 \% \\
11.2 \% \\
0.0 \% \\
41.0 \% \\
2.4 \% \\
1.8 \% \\
0.2 \% \\
0.0 \%\end{array}$ & $\begin{array}{l}0.0 \% \\
0.0 \% \\
0.2 \% \\
0.2 \% \\
72.4 \% \\
0.0 \% \\
0.6 \% \\
0.0 \% \\
1.2 \%\end{array}$ \\
\hline $\begin{array}{c}\text { Proerythroblasts } . . \\
\text { Normoblasts, early } \\
\text { intermediat } \\
\text { in late }\end{array}$ & $\begin{array}{l}\text {.. } \\
\ddot{\mathrm{te}} \\
\cdots\end{array}$ & $\begin{array}{r}0.2 \% \\
3.6 \% \\
11.0 \% \\
3.4 \%\end{array}$ & $\begin{array}{l}0.0 \% \\
0.0 \% \\
0.0 \% \\
0.0 \%\end{array}$ \\
\hline $\begin{array}{ll}\text { Lymphocytes } & . \\
\text { Monocytes } & . \\
\text { Plasma cells } & \ldots \\
\text { Reticulum cells } & \ldots \\
\text { Macrophages } & \ldots\end{array}$ & $\begin{array}{ll}\cdots & \cdots \\
\cdots & \cdots \\
\cdots & \cdots \\
\cdots & \cdots\end{array}$ & $\begin{array}{l}19.6 \% \\
2.8 \% \\
0.4 \% \\
0.0 \% \\
0.0 \%\end{array}$ & $\begin{array}{l}12.4 \% \\
12.4 \% \\
0.6 \% \\
0.0 \% \\
0.0 \%\end{array}$ \\
\hline Megakaryocytes .. &.. & $0.2 \%$ & $0.0 \%$ \\
\hline Myeloid/erythroblast ratic & io & $323: 1$ & - \\
\hline
\end{tabular}

depression which followed multiportal techniques when giving $400 \mathrm{kV} x$-ray therapy to approximately $2,000 \mathrm{r}$ tissue dose over a total period of two months in a patient with a disseminated testicular tumour. They were able on two quite distinct occasions to restore to more normal limits severely depressed peripheral blood-cell counts. A further patient with renal carcinoma was given $700 \mathrm{r}$ centre dose to the torso in 10 days, presumably at the same kilovoltage as the first patient. Here no benefit followed the bone-marrow infusion. Both their patients died-the first four months after the initial marrow infusion, and the second 10 days after the injection of bone marrow. This valuable work demonstrated clearly the ability of the body to reaccept stored autogenous marrow even though the therapeutic effect of the radiation was disappointing.

It was decided to treat the entire thorax of selected patients with multiple pulmonary metastases by means of the $2 \mathrm{MeV}$ Van de Graaff generator. This apparatus has certain advantages, as described below, when compared with more conventional machines. It was anticipated that the treatment of such large volumes of tissue, apart from the haematological effects, must inevitably result in considerable constitutional disturbance with much nausea, vomiting, and distress. Therefore it was decided to shorten the overall treatment time in an attempt to obtain a uniform dose of 3,000 r in two weeks. This programme has now been carried out in two cases. Somewhat to our surprise, it was found that one (Case 2) of the two patients tolerated this course of treatment with virtually no constitutional disturbance whatsoever. This does not, of course, refer to the haematological response which is mentioned in the description of the individual cases.

Case 1

A woman aged 22 was referred to Sir Stanford Cade on February 13, 1957, with pain in the right wrist of three or four weeks' duration. She was found to have a highly vascular bone lesion at the lower end of the right ulna, which on clinical and radiographic grounds was thought to be an osteogenic sarcoma. In view of the vascularity, biopsy was not done. Treatment was given by means of $2 \mathrm{MeV} x$ rays from February 19 to April 15 to a maximum tumour dose of $7,000 \mathrm{r}$. This resulted in complete relief of pain and marked recalcification of the tumour. The patient remained well until she attended the hospital on September 10,1958, complaining of dyspnoea and loss of 